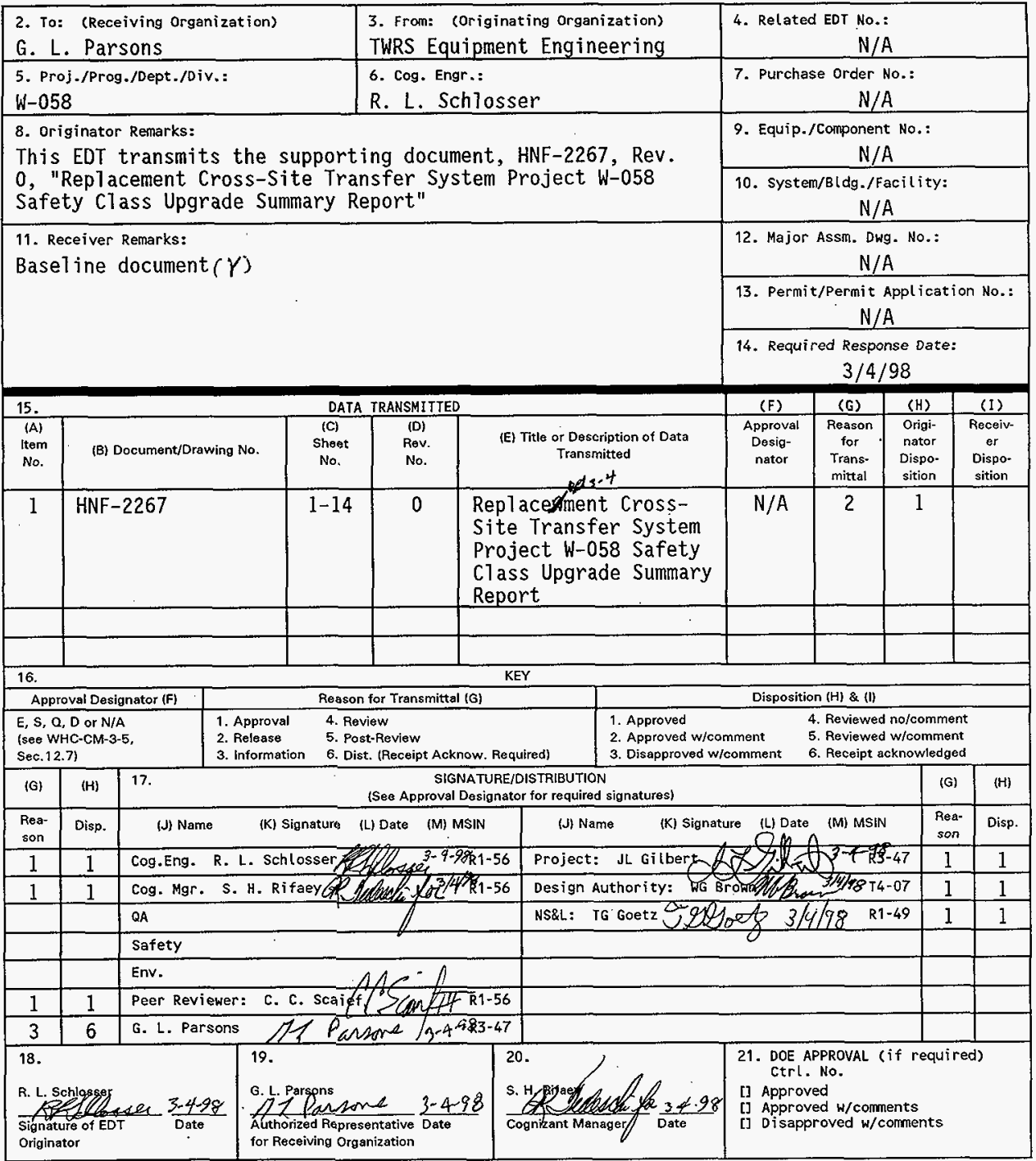

BD-7400-172-2 (04/94) GEF097 


\section{Replacement Cross-Site Transfer System Project W-058 Safety Class Upgrade Summary Report}

R. L. Schlosser

Lockheed Martin Hanford Corporation, Richland, WA 99352

U.S. Department of Energy Contract DE-AC06-96RL13200

EDT/ECN: $618226 \quad$ UC: 2030

Org Code: 74731 Charge Code: N58FR

B\&R Code: 39EW31301 Total Pages: 17

Key Words: cross-site transfer, waste transfer

Abstract: This report evaluates the design of the replacement crosssite transfer system structures, systems, and components for safety related applications as defined in the Tank Waste Remediation Systems Basis for Interim Operations.

TRADEMARK DISCLAIMER. Reference herein to any specific commercial product, process, or service by trade name, trademark, manufacturer, or otherwise, does not necessarily constitute or imply its endorsement, recommendation, or favoring by the United States Government or any agency thereof or its contractors or subcontractors.

Printed in the United States of America. To obtain copies of this document, contact: WHC/BCS Document Control services, P.0. Box 1970, Mailstop H6-08, Richland WA 99352, Phone (509) 372-2420; Fax (509) 376-4989.
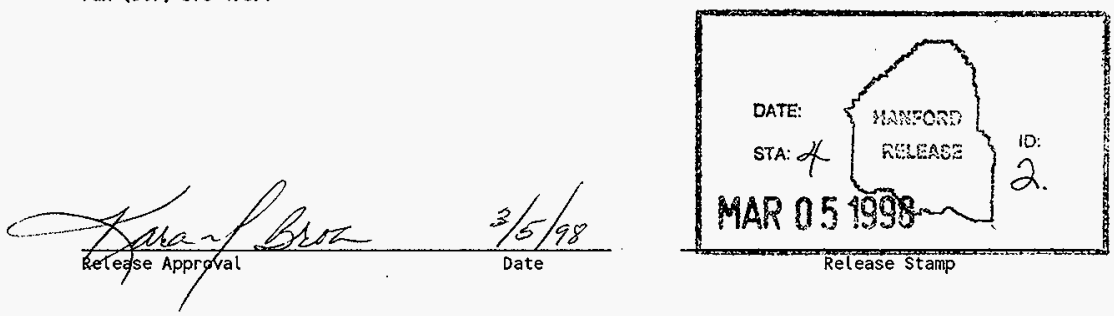


\section{REPLACEMENT CROSS-SITE TRANSFER SYSTEM PROJECT W-058}

SAFETY CLASS UPGRADE SUMMARY REPORT

HNF-2267, Revision 0

R. L. Schlosser

Lockheed Mart in Hanford Corporation

March 4, 1998 
HNF-2267, Rev. 0

CONTENTS

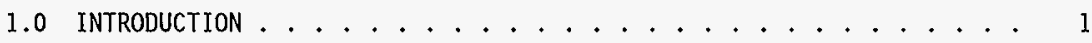

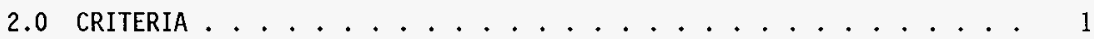

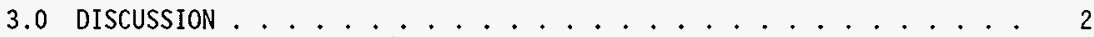

3.1 Diversion Box and Vent Station Structures .......... . 2

3.2 Encasements ................. 3

3.3 Pit Leak Detection Systems . . . . . . . . . . . . . . . 3

3.4 Service Water Pressure Detection System . . . . . . . . . . 4

3.5 Diversion Box and Vent Station HEPA Inlet Seal Filters.... 5

3.6 RCSTS Pressure Relief Valves and Rupture Disks . . . . . . . 5

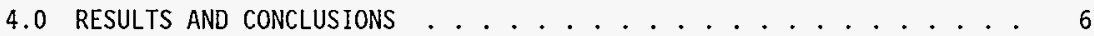

4.1 Diversion Box and Vent Station Structures ......... 6

4.2 Encasements ................. 6

4.3 Pit Leak Detection Systems ................ 6

4.4 Service Water Pressure Detection System . . . . . . . 7

4.5 Diversion Box and Vent Station HEPA Inlet Seal Filters.... 7

4.6 RCSTS Pressure Relief Valves and Rupture Disks . . . . . . 7

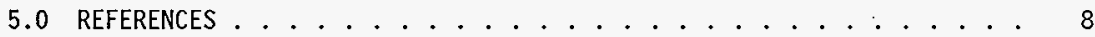

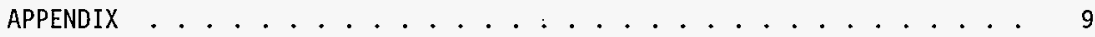


HNF-2267, Rev, 0

\subsection{INTRODUCTION}

This report summarizes equipment design, procurement, and construction of the Replacement Cross Site Transfer System (RCSTS) Project W-058 against

requirements of the Tank Waste Remediation System Basis for. Interim Operation (BIO), (LMHC, 1997). The Safety Evaluation Report (DOE, 1997) for the RCSTS directed performance of engineering studies for the pipe encasements, pit leak detection systems, and service water pressure detection system which were originally designated to a lower safety classification than that required by the BI0 analyses. A detailed evaluation of the pipe encasements, pit leak detection systems, and service water pressure detection system is included with this summary to respond to the Safety Evaluation Report conditions.

Safety of the RCSTS design was initially evaluated in the Replacement of the Cross-Site Transfer Line Preliminary Safety Analysis Report (WHC, 1996). Based on that evaluation, the safety designation of pipe encasements was changed to Safety $\mathrm{Cl}$ ass 1 (equivalent to Safety Class). Pit leak detection systems were designated Safety Class 2 (equivalent to Safety Significant) and the service water pressure detection system was designated Generat Service.

The BIO classifies pit cover blocks, transfer line encasements, transfer pit leak detection systems, and service water pressure detection systems as Safety Class. A proposed change to the BIO was submitted (FDH, 1997) to incorporate the RCSTS. Based on this proposal, the U.S. Department of Energy, Richland Operations office (RL) authorized startup and operation of the RCSTS with added classification of the diversion box and vent station high efficiency particulate air (HEPA) inlet filters as Safety Significant and rupture disks and relief valves protecting downstream piping as Safety Class (DOE, 1997).

The safety functions for RCSTS structures, systems, and components (SSCs) are summarized in the Appendix, identifying the various classification levels applied to the SSCs for the accidents analyzed or addressed by the BIO and imposed or added based on specific analyses for the RCSTS.

Evaluation is provided to identify whether deficiencies exist for these SSCS relative to imposition of Safety Class requirements.

The purpose of this report is to determine if the systems and components provided by the project can meet current safety requirements and recommend those measures which can be taken to meet the requirements, if warranted.

\subsection{CRITERIA}

Design, procurement, construction, and test criteria are imposed on Safety Class structures, systems, and components (SSCs).

Procurement, construction, and test criteria relate primarily to the quality assurance applied to ensure that functions are satisfied.

The same procurement and quality requirements appiy for both Safety Significant and Safety Class components (FDH, 1998). Therefore, it is possible to upgrade the Safety Significant items to Safety $\mathrm{Class}$ based on a 
HNF-2267, Rev. 0

review of existing vendor submittal and other project documentation against the safety functions and failure modes and effects of the BIO. For components which are procured to general service requirements, vendor documentation may not provide a sufficient basis for review, however these items may be accepted by application of a dedication process. The procurement process also governs construction, therefore, the construction of structures, systems and components may be likewise reviewed and accepted.

Testing requirements for all components and systems ensure their operation, for both safety and operational functions. As part of acceptance of the project, functional testing is being performed, ensuring that the components important to safety meet their design and safety functions. All instruments are calibrated as part of completion of the project.

Natural phenomena design criteria appropriate for the location and function are established. Functional design criteria are imposed to provide ensured active safety function performance by redundant systems and application of emergency power supply and diversity, if appropriate for reliable performance of the safety function.

\subsection{DISCUSSION}

\subsection{Diversion Box and Vent Station Structures}

The diversion box and vent station structures, their cover blocks and access ports were initially classified equivalent to Safety Class. Structural penetrations were classified equivalent to Safety Significant.

The diversion box and vent station structures were designed, procured, and constructed to criteria equivalent to Safety Class, including natural phenomena design for seismic and high wind conditions. The access corridors from the diversion box and vent station to their respective support buildings have been designed suitably for system interactions.

Access ports, penetrations, and entry doors were designed, procured, and constructed to criteria equivalent to Safety Significant. The natural phenomena seismic design criterion for access ports, penetrations, and entry doors is less stringent $(0.15 \mathrm{~g})$ than the criteria $(0.20 \mathrm{~g})$ imposed on Safety $\mathrm{Cl}$ ass components. However, design analyses for the access ports, building penetrations, and entry doors applied the more stringent $0.20 \mathrm{~g}$ loading. Therefore, these components comply with appropriate natural phenomena requirements for Safety $\mathrm{Class}$ application.

Since the quality requirements imposed on all components are equivalent to those applied to Safety $\mathrm{Cl}$ ass components, the structures, entry doors, and penetrations meet quality requirements.

The corridor and stair between the diversion box and the diversion box support facility have been designed to appropriate interface requirements for interconnection to a Safety $\mathrm{Cl}$ ass structure. Likewise, the corridor between the vent station and the vent station support facility have been designed to appropriate interface requirements. 
HNF-2267, Rev. 0

\subsection{Encasements}

The encasements were classified as Safety Class 3 in the Technical Requirements Buried Pipeline for Replacement of The Cross Site Transfer System (ICF KH, 1995) as issued July 28,1995 . The encasement classification was changed to Safety $\mathrm{Class} 1$ by Engineering Change Notice (ECN) W058-022 (ICF KH, 1996) in January 1996 based on the classification developed (WHC, 1996).

The specification was approved in August 1995 and the contract was awarded in December 1995. Initial contract work was limited and the encasements were procured and installed subsequent to a negotiated change to the contract to incorporate ECN W058-022. Therefore, al1 Safety $\mathrm{Cl}$ ass requirements have been satisfied for the encasement piping.

The design of the transfer line environmental leak detection system was to detect the specific location of any transfer line leakage, operating the system with the encasement lines isolated from the diversion box and vent station pits. In the event of a leakage condition, the encasement line would pressurize and, when a pressure of 60 pounds/square inch gage was reached, rupture disks would actuate to divert the leakage to either the diversion box or vent station. The rupture disks were purchased to the same requirements as the encasement piping. Therefore, all Safety $\mathrm{Class}$ requirements have been satisfied for the encasement rupture disks.

\subsection{Pit Leak Detection Systems}

The transfer pit leak detection systems in Diversion Box 6241-A and Vent Station 6241-V were classified as Safety Class 2 (WHC, 1996). The pit leak detection systems have been designated as Safety Class as part of Addendum 2 (LMHC, 1998) to the BIO. The original design relied upon safety classification of the transfer piping. Therefore, pit leak detection was only relied upon to alert the operators to a leak condition (WHC, 1996), a Safety Class 2 function.

The pit leak detection systems in the 6241-A Diversion Box and the 6241-V Vent Station were procured and installed to requirements equivalent to Safety Significant criteria. Since these components are relied upon to terminate a transfer should a leak occur, their Safety Class function requires that they actuate upon leak detection, actuate upon loss of power or be provided with emergency power to ensure continued detection, and that they do not have a failure mode which would prevent actuation. Due to their location within the structures, natural phenomena design for wind is not applicable.

Both leak detectors, LDE 3150 at the diversion box and LDE 3151 at the vent station, are Fluid Components International Mode1 8-66 Liquid Level/Interface controllers. These components operate by indication of thermal dispersion. The instruments utilize a heater as a thermal source and have two resistance temperature detectors (RTDs), one proximate to the heating element (sensing element) and the second, remote (reference element). If a liquid is present, heat from the source is dissipated, decreasing the difference in temperature sensed by the RTDS. The differential between the RTDs is monitored, and if 
HNF-2267, Rev. 0

reduced below a calibrated setpoint, the trip signal is generated. 0n loss of power to the detector, the detector design is fail safe: the heater will no longer provide a differential temperature and the low differential contact will open, simulating detection of a leak. Based on the operational principle, the sensor is a fail-safe device for loss of power, faiture of the heating element, and for failure of the sensing element RTD. However, failure of the reference element RTD does not provide a trip signal.

The trip signal is transmitted through a series of relays wired to provide a trip signal in the event of a loss of electrical power and provide an open contact in the transfer pump trip circuit.

As designed, the leak detection system does not provide redundant protection. Based on the relative costs to provide a full evaluation for acceptability of non-redundant design, the project has issued ECN W058-381 (FDNW, 1998) to add redundant leak detectors and associated relays for the diversion box and vent station.

The leak detectors and their associated electrical components were procured and installed to requirements equivalent to Safety Significant. Therefore, Safety Class procurement requirements have been satisfied.

The natural phenomena seismic design criterion for leak detectors, leak detection relays, and diversion box and vent station electrical penetrations is less stringent $(0.15 \mathrm{~g})$ than the criteria $(0.20 \mathrm{~g})$ imposed on Safety Class components. However, design analysis for the detector and relay cabinet mountings and the building penetrations was performed applying the more stringent $0.20 \mathrm{~g} \mathrm{loading.} \mathrm{Therefore,} \mathrm{these} \mathrm{components} \mathrm{comply} \mathrm{with} \mathrm{appropriate}$ natural phenomena requirements for Safety Class application. The electrical conduit runs are routed and buried adjacent to the transfer lines. Since shutdown in a seismic event is an operator action, the pit leak detection systems have not been tested for operability during a seismic event.

\subsection{Service Water Pressure Detection System}

The service water pressure detection system at the 241-SY-A Valve Pit was procured as a commercial grade item. The service water pressure detection system has been designated as Safety Class. The project modification to jumper assemblies in the valve pit was performed to the requirements of the previous Authorization Basis, which credited check and manual valves as acceptable isolation. Pressure detection was utilized for prevention of contamination spread rather than as mitigation for postulated leak accidents.

The service water pressure detection system utilizes a pressure transmitter in the 241-SY-A Valve pit to sense and actuate a pump trip signal to terminate transfer upon detection of high pressure in the service water connection jumper upstream of a check valve and isolation valve. The system was procured to General Service criteria. Since this system is relied upon to terminate a transfer should pressure indicate valve leakage occurs, the Safety Class function requires that it actuate upon high pressure detection, actuate upon loss of power or be provided with emergency power to ensure continued detection, and that it does not have a failure mode which would prevent 
HNF-2267, Rev. 0

actuation. Natural phenomena design for wind conditions is not applicable to this system.

The pressure transmitter, PT-3113, is an Ametek Corporation Model 88C005A2 Electronic Pressure Transmitter with signal output of 4-20 mA. This design will not provide a trip signal should loss of power occur. The transmitter supplies a limit alarm, Action Instruments Model AP1090-2000-P which provides local alarm at the 24I-SY-271 Relay Cabinet. The limit alarm provides a hard wired fail-open trip connection to terminate transfer. The limit alarm output will provide a fail-safe trip signal on loss of power or on loss of input signaT. from the transmitter.

In addition to the safety function provided by the pressure transmitter, its location in the 241-SY-A Valve Pit also requires compliance with ignition source control requirements for the ex-tank region of a Facility Group 2 tank, 241-SY-102. The pressure transmitter is intrinsically safe only if installed with approved associated devices; however, the detectors as installed are nonincendive as required by the applicable ignition control requirements.

As designed, the service water pressure detection system does not provide redundant protection. Based on the relative costs to provide a ful1 evaluation for acceptability of a design which is neither redundant nor failsafe, the project has issued ECN W058-381 (FDNW, 1998) to add a redundant pressure transmitter, high pressure alarm, and trip connection to the detection system.

The natural phenomena seismic design criterion for pressure transmitters is less stringent $(0.10 \mathrm{~g})$ than the criteria $(0.20 \mathrm{~g})$ imposed on Safety Class components. However, the jumper design (and pressure transmitter mounting) was specifically evaluated to the higher loading criteria appropriate for Safety Class applications. Since shutdown in a seismic event is an operator action, the service water pressure detection system has not been tested for operability during a seismic event.

\subsection{Diversion Box and Vent Station HEPA Inlet Seal Filters}

The air inlet filters for the diversion box and vent station were designed, procured, and constructed to criteria equivalent to Safety Significant. Therefore, a 11 BIO requirements have been satisfied by the design.

\subsection{RCSTS Pressure Relief Valves and Rupture Disks}

From inception, the design of the RCSTS recognized the potential for system interaction with existing piping downstream of the system. The basic design to utilize a high pressure booster pump was accommodated at the system interface with downstream piping by inclusion of two sets of rupture disks and pressure relief valves to protect the downstream piping from overpressurization, by providing adequate relieving capacity to the 244-A Catch Tank. The overpressure protection system has been classified as Safety Class from inception, therefore, all BI0 requirements have been satisfied by the design. 
HNF-2267, Rev. 0

\subsection{RESULTS AND CONCLUSIONS}

\subsection{Diversion Box and Vent Station Structures}

The diversion box and vent station structures, including cover blocks, have been designed, procured, constructed, and tested to Safety Class criteria. Access ports and penetrations for air sampling, air inlet and exhaust, and emergency pumpout have been supplied to criteria equivalent to Safety Significant, meeting applicable procurement and construction criteria for Safety Class application; specific design to $0.20 \mathrm{~g}$ seismic conditions satisfies the natural phenomena design criteria required for the Safety $\mathrm{Class}$ application.

The entry door was designed, procured, constructed, and tested to criteria equivalent to Safety Significant. Therefore, quality requirements appropriate for Safety Class have been satisfied; specific design to $0.20 \mathrm{~g}$ seismic conditions satisfies the natural phenomena design criteria required for the Safety CTass application.

The liner washdown penetration materials were procured and installed to the same requirements as the other penetrations. The liner washdown penetrations are direct embedments in the concrete structure with an anchor plate embedded, identical in design to the air sampling penetration. Therefore, the liner washdown penetrations are bounded by the specific design to $0.20 \mathrm{~g}$ seismic conditions and meet the appropriate criteria.

Therefore, the BIO requirements have been satisfied for Diversion Box 6241-A, Vent Station 6241-V, and their associated access ports, penetrations, doors, and cover blocks.

\subsection{Encasements}

The encasement system for transfer 1 ines WT-SNL-3150 and WT-SLL-3160, including the encasement piping and the encasement rupture disks, have been designed and constructed to all applicable requirements for a Safety Class system. Therefore, this system is fully compliant with BIO requirements.

\subsection{Pit Leak Detection Systems}

The pit leak detection systems for the diversion box and vent station are designed, procured, and constructed to appropriate quality requirements. The detectors will fail safe on loss of power. Therefore, emergency power is not required for performance of their design safety function.

These detection systems are not currently designed to fail safe for a failure of the reference RTD. Therefore, redundant leak detection circuits (LDE-3I50A and $L D E-3151 \mathrm{~A}$ and their associated relays) have been added to provide a signal should the reference RTD in LDE-3150 or LDE-3151 fail. The pump trip interlock is a hard-wired circuit, therefore, interface with the process 
HNF-2267, Rev. 0

control unit (PCU) of the process monitoring and control system does not serve a safety function requiring qualification of the PCU software.

The pit leak detection systems have been supplied to Safety Significant criteria, meeting applicable procurement and construction criteria for Safety Class application; specific design to $0.20 \mathrm{~g}$ seismic conditions satisfies the natural phenomena design criteria required for this Safety Class application.

The BI0 requirements have been satisfied for the pit leak detection systems. Operability during a seismic event is not considered; therefore, operator termination of the transfer is relied upon as the response to a seismic event.

\subsection{Service Water Pressure Detection System}

The service water pressure detection system is designed, procured, and constructed to general service requirements. The pressure transmitter and high pressure alarm/switch are appropriately qualified for their intended safety function based on the critical characteristics of the application. Since the instruments are powered from the same supply as the transfer pump control circuit, the system is fail safe for loss of power. Therefore, emergency power is not required for performance of the design safety function.

This system is not currently designed to fail safe for a failure of the pressure transmitter or the high pressure switch. Therefore, a redundant circuit (PT-3113A and associated PSH-3113A and relays) has been added to provide signal should a component failure in PT-3113 or PSH-3113 occur. The pump trip interlock is a hard-wired circuit, therefore, interface with the PCU of the process monitoring and control system does not serve a safety function requiring qualification of the $\mathrm{PCU}$ software. The pressure transmitter installation was designed to appropriate seismic criteria for Safety Class applications. The transmitters are of nonincendive design, meeting appropriate ignition control requirements.

The BIO requirements have been satisfied by the service water pressure detection system design. Operability during a seismic event is not considered; therefore, operator termination of the transfer is relied upon as the response to a seismic event.

\subsection{Diversion Box and Vent Station HEPA Inlet Seal Filters}

The air inlet filters for the diversion box and vent station were designed, procured, and constructed to Safety Significant criteria. Therefore, the BIO requirements have been satisfied by the system design.

\subsection{RCSTS Pressure Relief Valves and Rupture Disks}

The pressure relief valves and rupture disks were designed, procured and installed to Safety Class criteria. Therefore, all BIO requirements have been satisfied by the design. 
HNF-2267, Rev. 0

\subsection{REFERENCES}

DOE, 1997: Letter, J. D. Wagoner (RL) to H. J. Hatch (FDH), Contract Number DE-AC06-96RL13200 - Approval of Authorization Basis (AB) Amendment Package for Project $W$-058, Replacement Cross-Site Transfer System, 97WSD-247, December 15, 1997, US Department of Energy - Richland Operations Office, Rich1and, Washington.

LMHC, 1997: Tank Waste Remediation System Basis for Interim Operation, HNF-SD-WM-BIO-001 Revision OG, December 30, 1997, Lockheed Mart in Hanford Corporation, Richland, Washington.

FDH, 1997: Letter, H. J. Hatch (FDH) to J. D. Wagoner (RL), Contract Number DE-AC06-96RL13200; Transmittal of Tier II Review Comment Resolutions and Revised Authorization Basis Amendment Package for Project W-058, Replacement Cross-Site Transfer System, FDH-9758105A Rl, October 15, 1997, Fluor Daniel Hanford, Inc., Richland, Washington.

FDH, 1998: Contro7 of Purchased Items and Services, HNF-PRO-268 Revision 1, January 8, 1998, Fluor Daniel Hanford, Inc., Richland, Washington.

FDNW, 1998: G. J. Kubinski, Engineering Change Notice W-058-381, January 19, 1998, Fluor Daniel Northwest, Richland, Washington.

ICF KH, 1995: Technical Requirements Buried Pipeline for Replacement of The Cross Site Transfer System, Specification W-058-C1, July 28, 1995, ICF Kaiser Engineers Hanford Company, Richland, Washington.

ICF KH, 1996: J. R. Collins, Engineering Change Notice W-058-22, January 26, 1996, ICF Kaiser Engineers Hanford, Rich Tand, Washington.

WHC, 1996: Replacement of The Cross-Site Transfer System Preliminary Safety Analysis Report, WHC-SD-W058-PSAR-001 Revision 1, January 4, 1996, Westinghouse Hanford Company, Richland, Washington. 
HNF-2267, Rev. 0

APPENDIX

This appendix provides a summary matrix of safety structures systems and components included in the RCSTS 
MATRIX OF RCSTS SAFETY STRUCTURES, SYSTEMS, AND COMPONENTS

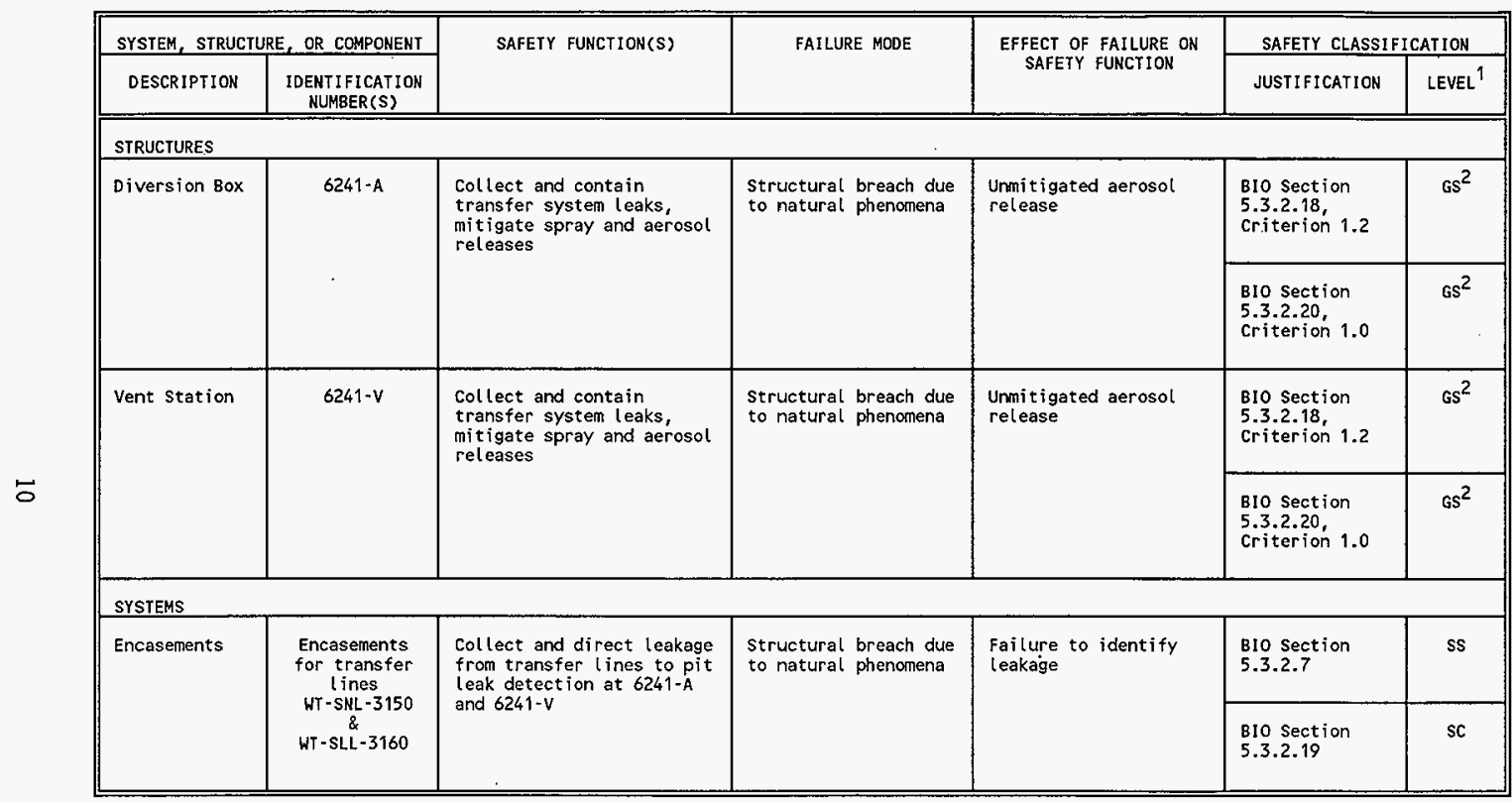


MATRIX OF RCSTS SAFETY STRUCTURES, SYSTEMS, AND COMPONENTS (continued)

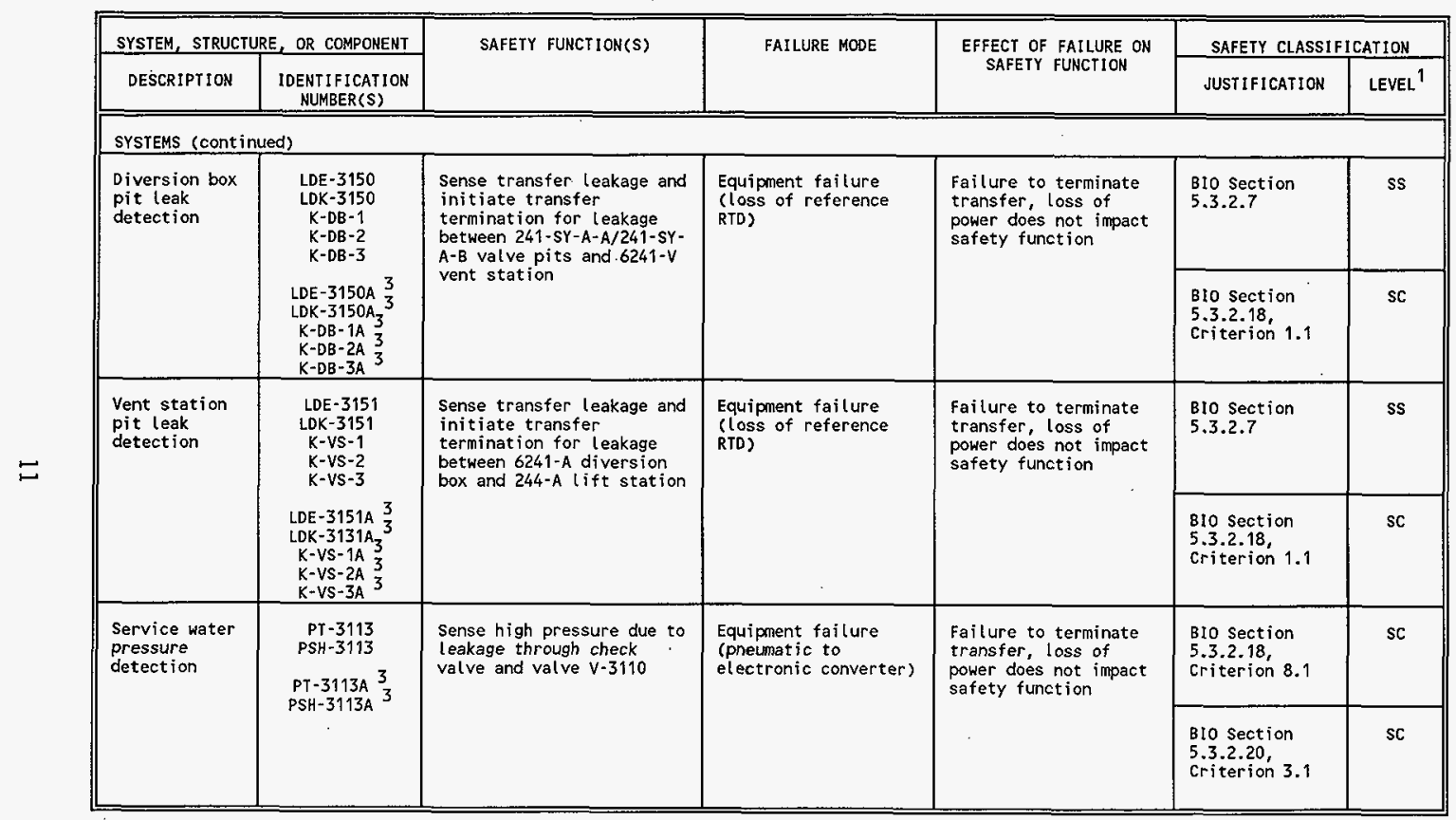


MATRIX OF RCSTS SAFETY STRUCTURES, SYSTEMS, AND COMPONENTS (continued)

\begin{tabular}{|c|c|c|c|c|c|c|}
\hline \multicolumn{2}{|c|}{ SYSTEM, STRUCTURE, OR COMPONENT } & \multirow[t]{2}{*}{ SAFETY FUNCTION(S) } & \multirow[t]{2}{*}{ FAILURE MODE } & \multirow{2}{*}{$\begin{array}{l}\text { EFFECT OF FAILURE ON } \\
\text { SAFETY FUNCTION }\end{array}$} & \multicolumn{2}{|c|}{ SAFETY CLASSIFICATION } \\
\hline DESCRIPTION & $\begin{array}{l}\text { IOENTIFICATION } \\
\text { NUMBER(S) }\end{array}$ & & & & JUSTIFICATION & LEVEL $^{1}$ \\
\hline \multicolumn{7}{|l|}{ COMPONENTS } \\
\hline \multirow[t]{2}{*}{$\begin{array}{l}\text { Diversion box } \\
\text { cover blocks } \\
\text { and access } \\
\text { ports }\end{array}$} & \multirow[t]{2}{*}{$6241-\mathrm{A}$} & \multirow[t]{2}{*}{$\begin{array}{l}\text { Limit release of aerosols, } \\
\text { limit shine }\end{array}$} & \multirow[t]{2}{*}{$\begin{array}{l}\text { Structural breach due } \\
\text { to natural phenomena }\end{array}$} & \multirow[t]{2}{*}{$\begin{array}{l}\text { Unmitigated aerosol } \\
\text { release }\end{array}$} & $\begin{array}{l}\text { 810 Section } \\
5.3 .2 .18, \\
\text { Criterion } 1.2\end{array}$ & ss \\
\hline & & & & & $\begin{array}{l}\text { Bto Section } \\
5.3 .2 .20, \\
\text { Criterion } 1.0\end{array}$ & sc \\
\hline \multirow[t]{2}{*}{$\begin{array}{l}\text { Diversion box } \\
\text { entry doors } \\
\text { and } \\
\text { penetrations }\end{array}$} & \multirow{2}{*}{$\begin{array}{l}\text { door 6; } \\
\text { air sample, } \\
\text { exhauster, } \\
\text { liner } \\
\text { washdown, and } \\
\text { emergency } \\
\text { pumpout } \\
\text { connect ions }\end{array}$} & \multirow[t]{2}{*}{ Limit release of aerosols } & \multirow[t]{2}{*}{$\begin{array}{l}\text { Failure to close door } \\
\text { or seal penetrations }\end{array}$} & \multirow[t]{2}{*}{$\begin{array}{l}\text { Unmitigated aerosol } \\
\text { release }\end{array}$} & $\begin{array}{l}\text { Blo section } \\
5.3 .2 .18^{4}\end{array}$ & ss \\
\hline & & & & & $\begin{array}{l}\text { BIO Section } \\
5.3 .2 .20^{4}\end{array}$ & $\mathrm{sc}$ \\
\hline \multirow{2}{*}{$\begin{array}{l}\text { Vent station } \\
\text { cover blocks } \\
\text { and access } \\
\text { ports }\end{array}$} & \multirow[t]{2}{*}{$6241-V$} & \multirow[t]{2}{*}{$\begin{array}{l}\text { Limit release of aerosols, } \\
\text { limit shine }\end{array}$} & \multirow[t]{2}{*}{$\begin{array}{l}\text { Structural breach due } \\
\text { to natural phenomena }\end{array}$} & \multirow[t]{2}{*}{$\begin{array}{l}\text { Unmi tigated aerosol } \\
\text { release }\end{array}$} & $\begin{array}{l}\text { Blo section } \\
5.3 .2 .18, \\
\text { criterion } 1.2\end{array}$ & ss \\
\hline & & & & & $\begin{array}{l}\text { BIo Section } \\
5.3 .2 .20 \\
\text { Criterion } 1.0\end{array}$ & sc \\
\hline
\end{tabular}


MATRIX OF RCSTS SAFETY STRUCTURES, SYSTEMS, AND COMPONENTS (cont inued)

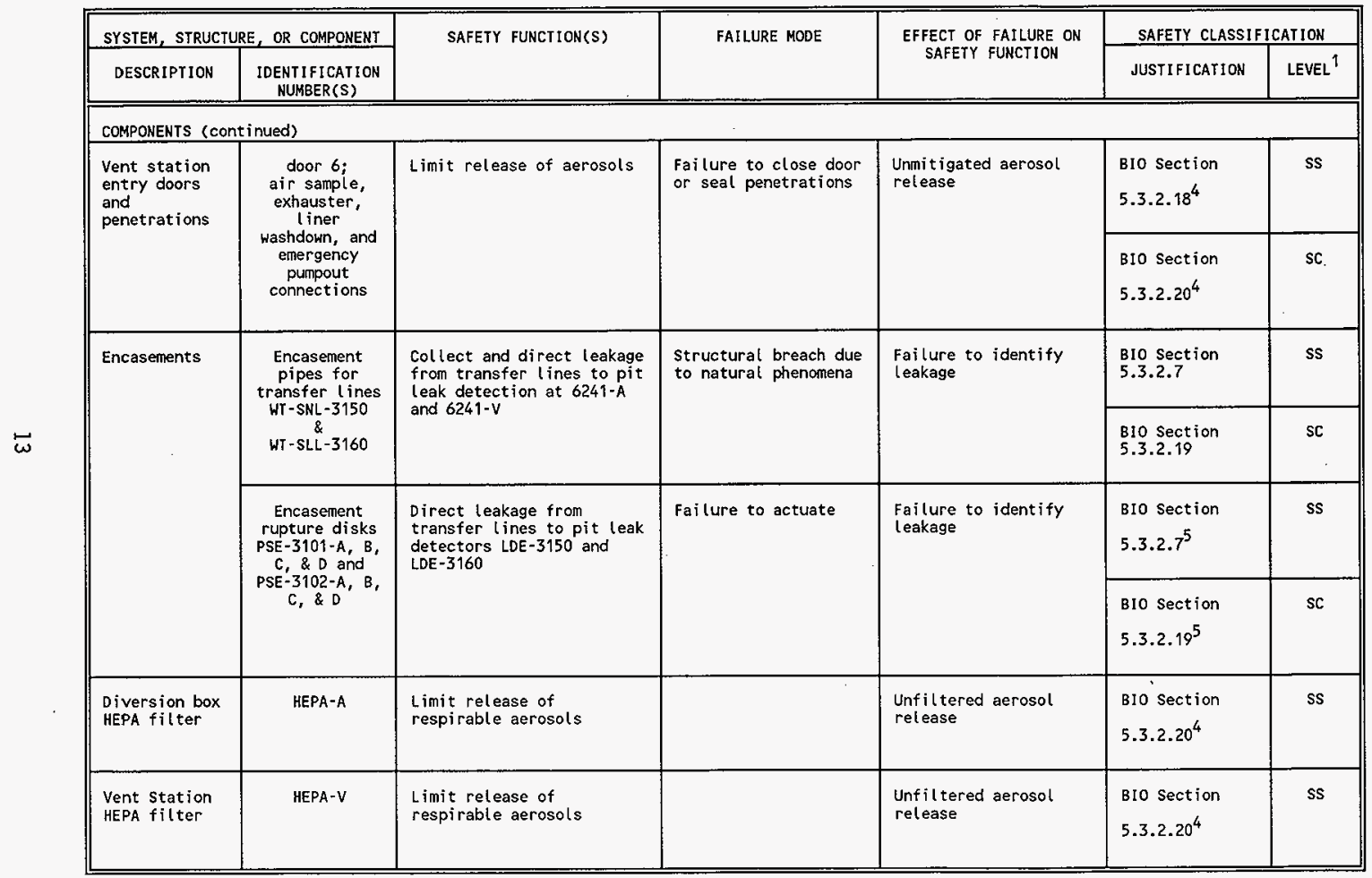


MATRIX OF RCSTS SAFETY STRUCTURES, SYSTEMS, AND COMPONENTS (continued)

\begin{tabular}{|c|c|c|c|c|c|c|c|}
\hline \multicolumn{3}{|c|}{ SYSTEM, STRUCTURE, OR COMPONENT } & \multirow[t]{2}{*}{ SAFETY FUNCTION(S) } & \multirow[t]{2}{*}{ FAILURE MODE } & \multirow{2}{*}{$\begin{array}{l}\text { EFFECT OF FAILURE ON } \\
\text { SAFETY FUNCTION }\end{array}$} & \multicolumn{2}{|c|}{ SAFEIY CLASSIFICATION } \\
\hline \multicolumn{2}{|r|}{ DESCRIPTION } & $\begin{array}{l}\text { IDENTIFICATION } \\
\text { NUMBER(S) }\end{array}$ & & & & JUSTIFICATION & LEVEL ${ }^{1}$ \\
\hline \multicolumn{8}{|c|}{ COMPONENTS (cont inued) } \\
\hline \multirow{3}{*}{\multicolumn{2}{|c|}{$\begin{array}{l}\text { RCSTS } \\
\text { pressure } \\
\text { relief valve } \\
\text { and rupture } \\
\text { disk }\end{array}$}} & \multirow[t]{3}{*}{$\begin{array}{l}\text { PRV-841 } \\
\text { PRV-842 } \\
\text { PSE-841 } \\
\text { PSE-842 }\end{array}$} & \multirow[t]{3}{*}{$\begin{array}{l}\text { Preclude overpressurizing } \\
\text { existing piping downstream } \\
\text { of RCSTS }\end{array}$} & \multirow[t]{3}{*}{ Failure to actuate } & \multirow[t]{3}{*}{$\begin{array}{l}\text { Overpressurization of } \\
\text { downstream piping }\end{array}$} & $\begin{array}{l}\text { 810 Section } \\
5.3 .2 \cdot 18^{4}\end{array}$ & sc \\
\hline & & & & & & $\begin{array}{l}\text { Bro Section } \\
5.3 \cdot 2 \cdot 19^{4}\end{array}$ & sc \\
\hline & & & & & & $\begin{array}{l}\text { BIO Section } \\
5.3 .2 .20^{4}\end{array}$ & sc \\
\hline \multicolumn{8}{|c|}{$\begin{array}{l}1 \text { Safety classification levels are SC for safety Class, ss for safety significant, and GS for General Services. } \\
2 \text { BIO does not classify the structures, however, a significant portion of the diversion box and vent station structures is above grade. } \\
\text { Portions of the structures above grade serve the same purpose as cover blocks for spray and aerosol mitigation as indicated in the } \\
\text { effect of failure identified. Therefore, al though classified General Services, these structures are included. Both structures meet } \\
\text { the requirements for a Safety class structure. } \\
3 \text { Components added by ECN w058-381. } \\
4 \text { BIO section reference is modified by Blo Addendum } 2 \text { as reanalyzed for incorporation of the Replacement Cross-site Transfer system. } \\
5 \text { For the RCsts encasenent environmental leak detection system, the design incorporates isolation of the encasement lines from the } \\
\text { diversion box and vent station pits during operation. Rupture disks direct leakage from the transfer lines to the pits for leak } \\
\text { detection when the encasement pressurizes to } 60 \text { psig. }\end{array}$} \\
\hline
\end{tabular}




\section{DISTRIBUTION SHEET}

\begin{tabular}{|c|c|c|c|c|c|}
\hline \multirow{2}{*}{$\begin{array}{l}\text { To } \\
\text { Distribution }\end{array}$} & \multirow{2}{*}{\multicolumn{3}{|c|}{$\begin{array}{l}\text { From } \\
\text { TWRS Equipment Engineering }\end{array}$}} & \multicolumn{2}{|l|}{ Page 1 of 1} \\
\hline & & & & \multicolumn{2}{|c|}{ Date March 4, 1998} \\
\hline \multicolumn{4}{|c|}{ Project Title/Work Order } & \multicolumn{2}{|c|}{ EDT No. 618226} \\
\hline \multicolumn{4}{|c|}{$\begin{array}{l}\text { Replacement Cross-Site Transfer System Project } W-058 \\
\text { Safety Class Upgrade Summary Report }\end{array}$} & \multicolumn{2}{|l|}{ ECN No. } \\
\hline Name & MSIN & $\begin{array}{l}\text { Text } \\
\text { With All } \\
\text { Attach. }\end{array}$ & Text Only & $\begin{array}{l}\text { Attach./ } \\
\text { Appendix } \\
\text { Only }\end{array}$ & $\begin{array}{l}\text { EDT/ECN } \\
\text { Only }\end{array}$ \\
\hline $\begin{array}{l}\text { W. G. Brown } \\
\text { J. L. Gilbert } \\
\text { T. G. Goetz } \\
\text { G. L. Parsons } \\
\text { C. E. Leach } \\
\text { S. H. Rifaey } \\
\text { C. C. Scaief III } \\
\text { R. L. Schiosser } \\
\text { Central Files }\end{array}$ & $\begin{array}{l}\text { T4-07 } \\
\text { R3-47 } \\
\text { R1-49 } \\
\text { R3-47 } \\
\text { R1-49 } \\
R 1-56 \\
\text { R1-56 } \\
\text { R1-56 } \\
\text { A3-88 }\end{array}$ & $\begin{array}{l}X \\
X \\
x \\
x \\
x \\
X \\
x \\
X \\
X\end{array}$ & & & \\
\hline project fited & R/-2 & $x$ & & & \\
\hline
\end{tabular}

